\title{
Gracián Dantisco and the Culture of Secrecy in Hapsburg Spain
}

\author{
Shifra ARMON \\ University of Florida \\ (sarmon@ufl.edu)
}

\begin{abstract}
RESUMEN
El tratado epistolar de buenos modales de Lucas Gracián Dantisco, El galateo español, representa un nexo temprano y decisivo en el debate sobre la disimulación en la España de los siglos XVI y XVII. Arguyo que la ética normativa de discreción dentro del micro-ámbito social de la corte autorizada por El galateo español prepara el terreno para la política de tapujo que se produciría a nivel estatal en el siglo siguiente. O sea, al demostrar la eficacia de callar dentro de la esfera de la sociabilidad cortesana, El galateo español auspiciaría la aceptación de guardar silencio dentro de la esfera más amplia de la diplomacia internacional
\end{abstract}

PALABRAS CLAVE: Conducta; Disimulación; Lucas Gracián Dantisco; Galateo español; Diego Saavedra Fajardo; Empresas políticas

\begin{abstract}
Lucas Gracián Dantisco's epistolary courtesy treatise, El galateo español, represents an early and important node in the debate on dissimulation in $16^{\text {th }}$ and $17^{\text {th }}$ century Spain. I argue that the normative ethics of discretion within the micro-climate of court that the Galateo español authorizes lays the groundwork for the politics of secrecy that takes hold at the level of the state during the following century. In other words, the Galateo español, by teaching the efficacy of concealment in the arena of courtly sociability, would serve to soften public opinion regarding the use of secrecy in the broader sphere of international diplomacy
\end{abstract}

KEY WORDS: Conduct; Dissimulation; Lucas Gracián Dantisco; Galateo español; Diego Saavedra Fajardo; Empresas políticas

Lucas Gracián Dantisco’s epistolary courtesy treatise, El Galateo español offers unique insight into the debate on dissimulation in $16^{\text {th }}$ and $17^{\text {th }}$-century Spain. ${ }^{1}$ Enthusiasm for Dantisco’s adaptation of Giovanni della Casa's 1558 El Galateo was high, prompting twenty reprintings in the two centuries that followed is first release in the late sixteenth century. ${ }^{2}$ Recent studies have linked the Galateo español to the picaresque, ${ }^{3}$ to Renaissance storytelling ${ }^{4}$ to the poetics of masculinity, ${ }^{5}$ and to reading habits at court. ${ }^{6}$

1 L. GRACIÁN DANTISCO, Galateo español, M. Morreale (ed.), Madrid, Consejo Superior de Investigaciones Científicas, 1968.

2 The precise publication date remains in question. Morreale documents the existence of two 1593 editions: Zaragoza and Barcelona., Morreale (ed.), 70-71. Felipe Ruan, citing González Sánchez, notes that the Galateo español was included in a 1583 inventory of books to be shipped to America, and that the dedication to Gonzalo Argote de Molina is dated 1582. F. RUAN, "Court, Market and the Fashioning of the Galateo español", Bulletin of Hispanic Studies 87.8 (2010), 921-938. Carlos Alberto GONZÁLEZ SÁNCHEZ, Los mundos del libro: medios de difusión de la cultura occidental en las Indias de los siglos XVI y XVII, Sevilla, Diputación de Sevilla; Universidad de Sevilla, Secretariado de Publicaciones, 2001. Stefano Prandi dates Dantisco's first edition to 1603. S. PRANDI (ed.), Galateo de Giovanni Della Casa, Torino, Einaudi, 2000, 1 . 
Yet Gracián Dantisco’s treatise is also relevant to discussions of razón de estado, particularly with respect to concern about the use of secrecy in negotiating matters of state. ${ }^{7}$ While Dantisco does not makes overt macro-political claims, the normative ethics of discretion in polite face-to-face interaction at court that the Galateo español authorizes helps to lay the groundwork for statesmen of the following century to validate a politics of secrecy. In other words, the Galateo español, by teaching the efficacy of concealment in the arena of courtly sociability, softens public opinion regarding the use of secrecy in the broader sphere of international diplomacy.

Some sixty years after the publication of Lucas Gracián Dantisco’s Galateo español, Diego Saavedra Fajardo would advise the young heir apparent to the Spanish throne, Baltasar Carlos, 'He who knows not how to dissimulate, knows not how to rule.' ${ }^{8}$ It may come as a surprise that Saavedra Fajardo, an avowed anti-Machiavellian, should so freely promote an ethos of secrecy rather than a more transparent mode of governance. ${ }^{9}$ Cardinal Gaspar de Quiroga had placed Machiavelli on the Index of 1583, making Saavedra Fajardo's appeal to dissimulation appear all the more dissonant, (and potentially dissident). The mere act of promoting expediency over moral scruple in early modern Spain ran the risk of being perceived as heterodox because, as Elena Cantarino explains,

3 H. SIEBER, "Literary Continuity, Social Order, and the Invention of the Picaresque", en Marina Brownlee and Hans Ulrich Gumbrecht (eds.), Cultural Authority in Golden Age Spain, Baltimore, Johns Hopkins University Press, 1995, 143-64.

4 S. MCDANIEL, "Lucas Gracián Dantisco and the 'Novela del gran soldán”, Hispanic Journal (2009), $129-140$.

5 J. RICO-FERRER, "In Earnest and in Jest: Disciplining Masculinity through Narration and Humor in The Spanish Galateo", en G. MILLIGAN and J. TYLUS, (eds.), The Poetics of Masculinity In Early Modern Italy and Spain,Toronto, Ontario, Centre for Reformation and Renaissance Studies, 2010, 267-291.

${ }^{6} \mathrm{~F}$. RUAN, 2010.

7 In fact, Della Casa (1503-1556) is credited with coining the terms ragion di Stato and ragion degli Stati [reason of state and reason of states] in his Orazione a Carlos V (1547). E. CANTARINO, "El concepto de razón de Estado en los tratadistas de los siglos XVI y XVII (Botero, Rivadeneira y Settala)”, Res Pública, 2 (1998), 7-24.

8 D. SAAVEDRA FAJARDO. Empresas políticas, S. López (ed.), Madrid, Cátedra, 1999. The Empresas are also known as Idea de un príncipe politico cristiano [Idea of a political Christian prince]. The Latin aphorism "Qui nescit dissimulare nescit regnare" is traditionally attributed to Louis XI of France (1423-1483). It serves as the motto for Impresse 43. S. López (ed.), $524 \mathrm{n}^{*}$. Unless otherwise noted, all translations are my own.

${ }^{9}$ Eleven years earlier Saavedra Fajardo had published an anti-Machiavellian treatise and precursor to the Empresas entitled Introducciones a la politica y raz76ón de Estado del rey católico don Fernando [Introductions to the politics and Reason of State of the Catholic King don Ferdinand], the first draft of which would later become the Empresas politicas. "Diego Saavedra Fajardo", $<<$ http://www.studiolum.com/en/cd01saavedra.htm $>>$. 
La indiferencia de Maquiavelo frente a la moralidad o inmoralidad de los medios empleados por el gobernante para conseguir sus fines políticos (la conservación y aumento del poder: razón de Estado) fue considerada como algo inadmisible por los pensadores políticos, para los cuales -aun teniendo en cuenta la novedad del Estado barroco y la necesidad de una justificación del poder-, la política no podía pasar por encima de la moral y de la religión cristiana (4). ${ }^{10}$

Yet the Franciscan censor who approved the 1642 edition of the Empresas politicas, Fray Pedro de Cuenca Cárdenas, held the volume in such high esteem that he all but apologized for having been obliged to question it. ${ }^{11}$

Political philosophers resolve the paradox of Spain's ongoing flirtation with Machiavellian tactics of governance in various ways. One claim is that the more than halfcentury that transpired between the publication of The Prince and its author's appearance on Quiroga's Index, had permitted many of Machiavelli's ideas-more or less accurately-to permeate Spanish thought too deeply for a mere swipe of the pen to expunge. Another is that Machiavelli did not monopolize the discourse on either power or dissimulation. Álamos de Barrientos’ 1614 Tácito español ilustrado con aforismos, for example, appropriated Roman historian CorneliusTacitus (56-117 C.E.) to teach “cómo se adquieren y cómo se conservan los estados". Deep affinities between Machiavelli and Tacitus were perceived as early as 1593 by humanist Antonio de Herrera in his translation of Giovanni Botero's influential anti-Machiavellian essay, Della ragion di stato. But references to Tacitus continued to provide political theorists access to a language of pragmatism while minimizing the dangers implicit in directly referencing Machiavelli. ${ }^{12}$ Of the 1,855 sources that Saavedra Fajardo cites throughout the Empresas politicas, for example, Sagrario López calculates that Tacitus accounts for the largest block: some 37 percent (68).

But if it is true that Saavedra Fajardo cloaks the politics of non-disclosure in the language of Tacitus, it is equally evident, if less widely acknowledged, that another source

10 E. CANTARINO, “Tratadistas político-morales de los siglos XVI y XVII (apuntes sobre el estado actual de la investigación)", El basilisco, 21 (1996), 4-7, $<<$ http://www.filosofia.org/rev/bas/bas22102.htm $>>$.

${ }^{11}$ Cuenca y Cárdenas adduces the words of Genesis 1.31 to pronounce Saavedra Fajardo's creation good: $V i d i d$ cuncta quae fecerat et erant valde bona, claiming that it needs no censor because it 'speaks for itself: "La obra es tal que solamente necesita de sí misma para su recomendación. SAAVEDRA FAJARDO, 167.

12 C. DAVIS, "Baltasar Álamos de Barrientos and the Nature of Spanish Tacitism", Nigel Griffin et. al. (eds.), Culture and Society in Habsburg Spain. London,Tamesis, 2001, 57-78. 
that authorizes secrecy as a social practice in his Empresas politicas is the discourse on courtly civility. The publication in 1528 of Castiglione's Il libro del Cortegiano [The Book of the Courtier] ${ }^{13}$ and in 1530 of Erasmus's De civilitate morum puerilium [A Handbook on Good Manners for Children] ${ }^{14}$ signaled a renewal of interest in codes of sociability that sprang from the increasingly clientelist structure of European society. L. Levy Peck famously compared the flow of "grace" or favor from the monarch downward through the social pyramid to a fountain, "cuyo agua fluye alcanzando hasta los últimos confines del reino."15 Amiability was the dipper extended to catch this precious flow, thereby assuring the protection and support of those with favor and influence to pass down. Often drawing on Cicero's De oficiis for models, Renaissance conduct literature taught the requisite skills for presenting a pleasing public face before friend and enemy alike. Thus, although Fray Pedro de Cuenca Cárdenas would interpret the Empresas as a treatise that "engendra reyes" (168), and even though Saavedra himself would refer to his impresse as a "cierta y segura carta de gobernar" (170) dedicated to the prince, these nods toward the mirror of princes tradition camouflaged a more ambitious and inclusive agenda: that of reconfiguring codes of aristocratic conduct to meet the pragmatic challenges of the $17^{\text {th }}$ century.

In his prologue, "Al lector", Saavedra Fajardo explains that he aspires to reach beyond the crown, to focus on grooming its subjects, particularly men of court thirsty for the Prince's approval and grace:

No me ocupo tanto en la institución y gobierno del príncipe, que no me divierta al de las Repúblicas, a sus crecimientos, conservación y caídas, y a formar un ministro del Estado y un cortesano advertido (176 “Al lector").

Reason of State for Saavedra Fajardo demands the fabrication of loyal and compliant subjects who have been primed to lubricate the wheels of empire and enhance the majesty of the royal office. In its didactic mission to elucidate the skills required of

13 B. CASTIGLIONE, The Book of the Courtier, Daniel Javitch (ed.), Charles S. Singleton (trans.), New York, W. W. Norton, 2002.

14 ERASMO DE ROTTERDAM, A Handbook on Good Manners for Children, E. Merchant, ed., London, Preface, 2008.

15 L. L. PECK, Court Patronage and Corruption in Early Stuart England, London, Unwin Hyman, 1990. Citado en H. PIZARRO LLORENTE, "Las relaciones del patronazgo a través de los Inquisidores de Valladolid durante el siglo XVI", en J. Mártinez Millán (ed.), Instituciones y élites de poder en la monarquía hispana durante el siglo XVI, Madrid, Universidad Autónoma de Madrid, 1992, 223-252. 
servants of state, the Empresas politicas coincides with other courtly conduct guides of the period, whose purpose, in Castiglione's now-classic formula, was to determine:

what form of Courtiership most befits a gentleman living at the courts of princes, by which he can have both the knowledge and the ability to serve them in every reasonable thing, thereby winning favor from them and praise from others; in short, what manner of man he must be who deserves the name of perfect Courtier, without defect of any kind (9).

Saavedra Fajardo strengthens the analogy between educating the prince and training his servants in the Empresas's Epithet, "Ludibria mortis" [Estragos de la muerte]. Here the topos of Death the Equalizer renders sovereigns "comunes. . . con los demás mortales" (1049). But in life the analogy works even better than in death, for most of the advice that Saavedra Fajardo offers to the prince also applies to his subjects. For instance, the hieroglyph accompanying Impresse 38, "Con halago I con rigor" depicts the taming of a colt by means of both currying-brush and $\operatorname{rod}^{16}$ (see figure 1 ). The monarch, as the Impresse goes on to explain, must inspire in his subjects both love and fear:

Que le amen porque no oye lisonjas, que le teman porque no sufre libertades. Que le amen por su benignidad, que le teman por su autoridad. Que le amen porque procura la paz, y que le teman porque está dispuesto a la guerra. De suerte que, amando los buenos al príncipe, hallen qué temer en él; y temiéndole los malos, hallen qué amar en él (492).

Saavedra Fajardo's counsel to the Prince applies equally well to courtiers and favorites who must maintain the loyalty and affection of inferiors. By way of delineating the ideal Christian prince, Saavedra Fajardo-himself knighted in the prestigious Order of Santiago in 1640 following decades of diplomatic service to the crown--produces a bivocal curriculum of urbane sociability for the latter Hapsburg court, readily deciphered as such by readers acculturated by the discourse on civil conversation.

Saavedra Fajardo's curriculum of urbane sociability instructs through its message and also through its medium. By juxtaposing word with image his Empresas unleash allegorical games of hide-and-seek that challenge the reader to disclose hidden political

${ }^{16}$ D. SAAVEDRA FAJARDO, Idea de un principe politico christiano, representada en cien empressas, Valencia, 1675, 231. Permission for reproduction of engravings in this article has been granted by the Rare Book Collection, George A. Smathers Libraries at the University of Florida; online in the University of Florida Digital Collections: www.uflib.ufl.edu/UFDC. 
meanings in conventional symbols (157). ${ }^{17}$ Such hybrid lexico-graphic riddles teach monarch and subject alike to approach the task of interpretation with caution. This is evident in Impresse 33, "Siempre el mismo" which portrays the dual reflection of a crowned lion in a broken mirror, symbolizing that the royal image remains the same even when fragmented (see fig. 2). However, the broken mirror that multiplies its singular source subverts the reassuring message it is meant to illustrate. Instead of inspiring trust in the appearance of things, it generates anxiety about the reliability of surface reflections.

Even more enigmatic is Impresse 46, "Fallimur opinione", which summons the principle of refraction to explicate the distorting effect of public opinion (see fig. 3). Just as transparent water refracts rather than reflects the extension of an oar submerged beneath its surface, making it look bent or broken, Saavedra Fajardo argues that the invisible medium of public opinion can distort a person's reputation, a message equally relevant to the sovereign and his vassals.

Although deceptive appearances provoked anxiety in the political arena, they enjoyed a privileged position in the realm of sociability. To remain in good standing with everyone, it was necessary to suppress frankness for the sake of tact, and to practice restraint at the expense of authenticity. Dissembling, dissimulation and selective concealment therefore assumed the positive function of optimizing good relations within the high-pressure nexus of the imperial court.

The semiotics of social interaction - the exchange of information, the giving and receiving of deference-included verbal, non-verbal and written codes. ${ }^{18}$ In face-to-face interactions, conversation served as much more than a medium; it became the message itself, the proving ground for displaying the courtier's worthiness to receive favor. Like Antonio de Guevara (1481-1545) a century earlier, Saavedra knew first-hand the perils and rewards of mastering those codes. ${ }^{19}$ For Guevara, conversation at the court of Charles $\mathrm{V}$ was an activity rich with performative potential but also fraught with risk. The

\footnotetext{
${ }_{17}$ B. NELSON, "Emblematic Representation and Guided Culture in Baroque Spain: Juan de Horozco y Covarrubias", en Tom Lewis y Francisco Sánchez, (eds.), Culture and State in Spain 1580-1850, New York, Garland, 1999, 157-195.

18 Notaries, scribes, diplomats and courtiers engaged in a lively epistolary culture that generated the publication of a subfield of courtesy literature devoted to the art of writing.See for example V. GUIRAL, Arte De Escribir (1501); F. LUCAS, Arte De Escrevir (1608); P. D. MORANTE, Nueba arte donde se destierran las ignorancias que hasta hoy ha habido en enseñar a escribir, (1616).

19 As noted above, Saavedra Fajardo occupied various high-level diplomatic posts in Rome (1610-1633) and Central Europe (1634-1646). S. López (ed.), 31.
} 
less spoken aloud at court the better, advised Guevara. If given the choice between the vice of gambling and that of gossip, Guevara preferred the former because slander could lead to even greater ruin than losing at cards:

Infame es el palacio do no saben sino jugar y maldito es el palacio do no saben sino murmurar, porque al fin menos mal es que se pierdan los dineros que no se roben las vidas de los prójimos. ${ }^{20}$

A further impetus for vigilance in speech came from the Spanish Inquisition, as it spread what French historian Bartolomé Bennassar has called its 'pedagogy of fear.'21 In an atmosphere of anonymous denouncements and closed-door trials, spontaneous speech and gesture posed real dangers, and speech acts (or speech-suppressing acts) that helped negotiate the widening gap between public and private spheres, gained appeal. ${ }^{22}$ Early modern dissimulation," notes Jon R. Snyder,

involved first and foremost the exercise of strict self-control over the expression of thoughts, emotions, or passions. As a practice of selfcensorship, dissimulation assisted those who sought not to reveal or disclose anything of their own interiority, but were at the same time intent upon not uttering any untruth to others. ${ }^{23}$

As authenticity took cover behind a public mask of amiability, dissimulation became a necessary tactic of urbane comportment.

The self-surveillance demanded by clientelist power relations ushered Spain into those "civilizing processes" that Norbert Elias would later trace at the French court of the same period. ${ }^{24}$ The genealogy of conduct that Elias posits-a gradual shift in normative social interactions among the elite at court from crude to refined; from spontaneous to deliberate and from identified with to detached from the natural rhythms of the bodyhelps resolve the apparent contradiction between Saavedra's anti-Machiavellianism and his enthusiasm for dissimulation. By the seventeenth century, dissimulation had become

\footnotetext{
20 A. de GUEVARA. Le Réveille-Matin des Courtisans ou Moyens Légitimes pour Parvenir à la Faveur et pour s'y Maintenir, Nathalie Peyrebonne (ed. y trans.), Paris, Honoré Champion, 1999, 148.

21 B. BENASSAR, La España del Siglo de Oro, Pablo Bordonava (trans.), Barcelona, Crítica, 1990.

22 The growing gulf between public face and private thought attracted the attention of skeptical philosophers, for whom issues of seeming and being, reality and its representation were central concerns. But while skeptics questioned the ultimate knowability of truth, the discourse on amiability balanced the costs and benefits associated with spectacles of disclosure and concealment.

${ }^{23}$ J. SNYDER, Dissimulation and the Culture of Secrey in Early Modern Europe, Berkeley, The University of California Press, 2009, 6.

${ }^{24}$ N. ELIAS, The Court Society, Edmund Jephcott (trans.), Oxford, Blackwell, 1983.
} 
indispensable for "acting" courteously; for veiling one's physicality behind a veneer of artificiality and for appearing in control of any situation.

Of course dissimulation was not new to the Renaissance; the challenge of establishing boundaries between non-disclosure and outright lying had challenged theologians for centuries. Thomas Aquinas, for example, had opined in opening the Summa's inquiry "On lying," "It seems that lying is not always opposed to truth." 25 While Aquinas rejected outright falsehood, he also discriminated among differing classes of false speech. He was willing to forgive three kinds of lying: "jocose" lies such as boasting that merely exceed the truth, lying by omission of truth, and lies committed in the service of a greater good. Only malicious lies; that is, lies intended to injure others, were, to his view, unpardonable. Aquinas's distinctions would continue to inform subsequent formulations of normative ethics, contributing to the creation of a culture of self-consciousness in the Renaissance that Jon Snyder has called a 'culture of secrecy.'

Sebastián de Covarrubias's 1611 Tesoro de la lengua links dissimulating with Aquinas's concept of partial truth:

Dissimular. No darse por entendido de alguna cosa; . . . Vellaco dissimulado, el que encubre su malicia. 26

'Not to let on that you understand something,' does not lean in either a positive or a negative moral connotation; it is merely a normative self-presentation strategy. Yet the Tesoro's second acceptation, cited above, links dissimulation with the moral laxness of scoundrels.

The semantic elasticity of dissimulation becomes even more pronounced in the Diccionario de Autoridades, published almost a century after the Tesoro, but relying heavily on $16^{\text {th }}$ - and $17^{\text {th }}$-century sources. ${ }^{27}$ In one entry, Autoridades blandly defines dissimulation is a "Modo artificioso de encubrir la intención u dar a entender otra de la que se tiene". However 'artificioso' itself was a notoriously ambiguous word, meaning, again according to Autoridades, alternately inventive and clever, or deceptive. So even here, dissimulation might be taken either as a morally neutral or intentionally deceptive feint.

${ }^{25}$ T. AQUINAS, Summa Theologiae: Latin Text and English Translation, New York, McGraw Hill, 1976, Second Part of Part Two, Justice, "Connected Virtues" (Observances), Question 110, "On Lying."

26 S. COVARRUBIAS HOROZCO, Tesoro de la lengua castellana o española según la impresia $\square$ on de 1611, B. M. Noydens y Martín de Riquer (eds.), Barcelona, Horta, 1943.

27 REAL ACADEMIA ESPAÑOLA, Diccionario de autoridades, Madrid, Gredos, 1963. 
Lucas Gracián Dantisco seems an unlikely purveyer of the art of social selffashioning. ${ }^{28}$ A notary, later charged with cataloguing the vast inventory of Philip II's library at the Escorial, Dantisco claims to have little patience for excessive shows of courtly deference:

... las cerimonias superfluas se deven evitar, las quales fueron de los antiguos menos usadas que no aora, y a este vano uso. . . llamamos impropriamente cerimonias (130).

Like its immediate Italian model and inspiration, Monsignior Giovanni della Casa's Il Galateo, published posthumously in 1558, the Galateo español, teaches the art of attaining and maintaining the approbation of others. For this reason, in Rafael Bellón's view, the text should be framed generically along with courtly literature and baroque literary translation (1) ${ }^{29}$ Marguerita Morreale characterizes the author as an "hombre práctico más que erudito" (18) and "menos ducho como traductor que el. . . Doctor Becerra", della Casa's first Spanish translator (19). Ironically, despite Dantisco’s professed ambivalence toward politeness displays, his adaptation turned out to be more popular than Becerra's among Spanish readers. ${ }^{30}$

As a humanistic code of amiability aimed at winning friends and influence, Dantisco's guidebook shows more concern for what sociolinguists call 'positive face,' or enhancing one's own prestige before others, than avoiding 'negative face' or unflattering, embarrassing social encounters. This accent on becoming more attractive and promoting favorable first impressions distingishes it from the more cautious, defensive tone that characterizes Castiglione’s Book of the Courtier of 1528. As Pura Guil remarks,

Es evidente que resulta fundamental [para Dantisco] la consideración del otro, el deseo de complacerle, la expresión de muestras

\footnotetext{
28 The phrase "self-fashioning" alludes to Stephen Greenblatt's ground-breaking study. S. GREENBLATT, Renaissance Self-Fashioning: From More to Shakespeare, Chicago, University of Chicago Press, 1980.

${ }^{29}$ En sus palabras, el Galateo español “. . . debe ser entendido desde dos ópticas: la de la literatura cortesana y la de las traducciones libres barrocas." R. BELLÓN BARRIOS, "Gracián Dantisco y el 'Galateo español': La versión española de un texto cortesano”, en Biblioteca Saavedra Fajardo de Pensamiento Politico Hispánico, <<http://saavedrafajardo.um.es/WEB/archivos/NOTAS/RES0097.pdf>>, 1-20.

30 The first Spanish translation was Domingo de Becerra's (1584). While truer to Della Casa's text, Becerra's translation did not approach the publishing success of Gracián Dantisco's version, for which Morreale documents sixteen extant editions between 1593 and 1699. For Aldo Scaglione, Il Galateo was "one of the most important exemplars of the subgenre of etiquette or courtesy books." A. D. SCAGLIONE, Knights at Court: Courtliness, Chivalry and Courtesy from Ottonian Germany to the Italian Renaissance, 253.
} 
de interés por él, evitando aquellos modales que «mostrano che la persona sia non curante d'altrui» (par. 56), y que todo ello redunda en beneficio de la cara positiva del receptor y, como consecuencia, de la del emisor, puesto que le hará «amabile», en su significado pasivo, es decir, 'digno de ser amado," y como se mantiene en el término italiano, sin el cambio de sentido, adquiriendo un valor activo, operado en castellano (248). ${ }^{31}$

The treatise's preoccupation with 'positive face' leaves little room for consideration of avoidance strategies such as concealment, but, as we shall see, Chapters 6 "De los mentirosos" and Chapter 9 "De las cerimonias" raise questions of integrity and authenticity that provide insight into $16^{\text {th }}$ century ideations of secrecy.

The Galateo español engages in various sorts of textual sleight-of-hand and demonstrates the efficacy of duplicity in many circumstances, at the same time it purports to cast a disapproving eye on dissimulation as a social practice. This disjunction invites a closer reading of Dantisco's treatise with an eye not only to what it preaches about concealment, but also to how concealment is practiced and valued within the text's short and extended narratives. By juxtaposing dissembling moves within the Galateo españols narrative interludes against more overtly didactic messaging, it becomes easier to understand how Saavedra Fajardo's censor of the following century (Fray Pedro de Cuenca Cárdenas) could have come so wholeheartedly to endorse the Empresas politica's defense of the art of political concealment despite its Machiavellian overtones.

As noted above, Dantisco finds most deference displays to be inappropriate and hollow. In this sense, dissimulation adheres to the very notion of courtesy. Bowing and ceremony belong in the sacral context of Church ritual, not on street-corners and in palace halls:

Las cerimonias se tomavan por aquella solemnidad que los sacerdotes usavan alrededor de los altares y en los divinos oficios, acerca de Dios y de las cosas sagradas. Y hase usurpado este nombre después acá que los hombres se començaron a reverenciar unos con otros con artificiosos modos, inclinándose y torciéndose de lado con reverencias, en señal de acatamiento, descubriendo sus cabeças y

31 P. GUIL, "El amable <<amabile>> del Galateo", Cuadernos de filología italiana, no. extraordinario (2000), 239-252. 
llamándose señores y otros títulos extraordinarios besándose las manos como si las tuvieran sagradas, o fueran sacerdotes (131). ${ }^{32}$

Transculturation produces a ridiculous parody of curial protocol with little intrensic worth. Polite gestures represent "una vana significación de honra y reverencia acerca de aquel a quien se haze acatamiento" (131). By comparing everyday deference displays (polite forms of address, hand-kissing) to the priestly rituals from which they derived, Dantisco defamiliarizes those acts and creates a critical distance that reveals their absurdity.

Deference displays are inherently insincere because they hide authentic feelings of indifference behind a façade of obligatory sociability:

y digo vana, en quanto nosotros honramos con la vista y apariencia a aquellos que con el coraçón no les haríamos acatamiento; y con todo esso la usamos por no salir de la costumbre (131).

Were it not for the pressures of social conformity, Dantisco claims he would dispense with tiresome "cerimonias". But social pressure obliges the man of court to dissimulate the dictates of his heart beneath a veneer of civility. ${ }^{33}$

Civility rather than morality is also the yardstick against which the Galateo español measures lying. Here, the author proves to be less tolerant than Aquinas, whose sole concern was with the morality of exaggerated speech, not its consequences for the speaker. In Chapter 6, 'De los mentirosos', Dantisco reproves two types of liars for violating the core value of pleasing others. The first type exaggerates excessively, often for the very purpose of pleasing others. Yet this tactic can backfire by boring listeners or insulting their credulity, as seen in the anecdote of the man and the pitcher. One day, a man boasted that in order to quench his thirst, he shot an arrow at a pitcher of water high above on a window ledge, drank his fill from the flow, and then shot a second arrow right into the first hole, completely staunching the leak. But instead of gratifying his listerners, the braggart only angered them:

\footnotetext{
32 Here Dantisco ratifies Ernst Curtius's view, more recently endorsed by Aldo Scaglione, that European courtliness evolved out of the medieval curial courts.. E. R. CURTIUS, European Literature and the Latin Middle Ages, Princeton, New Jersey, Bollinger Foundation-Princeton University Press, 1990.

33 Dantisco's complaint anticipates that of the Governor of Cervantes's one-act farce, El retablo de las maravillas [The marvellous puppet-show], who laments the fact that la negrilla bonra [vile honor] requires him to pretend that he is seeing a non-existent performance. M. de CERVANTES, Entremeses, Madrid, Cátedra, 1994.
} 
Y aunque fue bien reída la mentira, uno de los que allí estavan, conocióle el humor tan jactancioso, enfadado dello, le dixo:

--Señor, V. M. gasta su tiempo en balde y nos cansa a todos, y quien esto nos quiere persuadir, o nos tiene por innocentes o por enemigos (125).

The 'plague' of exaggeration also damages credibility, so that people no longer believe anything such liars say unless they bring a witness to confirm the veracity of their story (125).

Telling an untruth was known as simulation. The verb 'simular' was defined by the Diccionario de Autoridades as "Representar alguna cosa, fingiendo o imitando lo que no es". Spanish humanist Juan Pablo Mártir Rizo (1593-1642), writing a century after Dantisco, would condemn simulation, but, like his contemporary, Saavedra Fajardo, he considered dissimulation to be an indispensible tool of statecraft:

La disimulación es muchas veces no sólo conveniente, pero forzosa. Ella y la simulación difieren en que la disimulación es no manifestar lo que uno ha sabido o sospechado y la simulación es decir o prometer una cosa y pensar hacer otra, que es engañar, cualidad indigna de un príncipe, y aun de los hombres inferiores (Norte 119). ${ }^{34}$

French historian Jean-Pierre Cavaillé in a recent study on simulation and dissimulation in early modern France maintains a similar dissocation between the two. "It is one thing to keep a secret," Cavaillé contends, "and another thing to lie."35

The act of simulation rigs the rhetorical contest by absenting truth. As William Kennedy has written, "In writing as in speech the audience participates in a rhetorical contest with the producing agent" (228). ${ }^{36}$ The speaker or 'producing agent,' who simulates displaces truth altogether, making it irrecuperable. But dissimulation, by merely covering up, overstating or omitting certain facts allows a fair rhetorical contest between audience and producing agent to take place. The truth remains present and available to be disclosed, uncovered, discerned.

34 J. P. MÁRTIR RIZO, Norte de Príncipes y Vida de Rómulo, Antonio Maravall (ed.), Madrid, Instituto de estudios políticos, 1945.

35 "une chose est garder un secret; une autre mentir," J. P. CAVAILLÉ, Dis/simulations. Jules-César Vanini, Francois La Mothe La Vayer, Gabriel Naudé, Louis Machon et Torquato Accetto: Religion, morale et politique an XVIIe siècle, Paris, Honoré Champion, 2002, en J. SNYDER, xvi, trans. p. 180 n. 13.

36 W. KENNEDY, "Voice' and 'Address' in Literary Theory", Oral Tradition 2.1 (1987), 214-30. 
Even non-utterance can be actively deceptive or mendacious however, according to Dantisco, who declares, "Puédese mentir también callando" (126). That is, the difference between lying and concealment does not rest, for Dantisco, in the distinction between passivity (not speaking) and active utterance. To illustrate, he points to those who misrepresent their station by draping themselves with medals, jewelry and rings:

que ponen su valor en sola la corteza y apariencia; cosas bien desapazibles y desconformes de lo que es razón y buena costumbre (126).

Such pompous peacocks are compared to monkeys who merely ape the powerful yet fail to diagnose their own 'illness' or seek a cure for their vanity.

Dantisco identifies three motives for engaging in courtesy rituals, all three of which entail differing degrees of dissimulation: 'por utilidad', 'por vanidad' and 'por obligación'. At one extreme, he condemns expedient courtesy as dishonest and immoral:

Por utilidad se entiende toda mentira que se dize por interés y provecho proprio del que la dize; y esta tal es fraude o pecado y deshonesta cosa, pues jamás se puede mentir honestamente (132).

Among those who resort to this ruse he points to 'chameleons' who change color to blend with their environment, false friends and flatterers.

Self-promoting courtesies 'por vanidad' consist of inflationary excess in the display of deference thst oblige others to reciprocate. These Dantisco dispatches quickly as “enojosas y desapazibles por ser tan contra lo que es verdad” (132).

Much more ink is spilled expounding upon courtesy 'por obligación' than 'por utilidad'or 'por vanidad'. The Spanish court was notorious for its punctiliousness, and these unavoidable niceties could actually cause harm in the breach by displeasing, insulting or offending others. Dantisco warns that obligatory or dutiful ceremony can easily get out of hand, but when practiced in moderation it is merely 'a sin of our times' (“no es pecado nuestro sino del siglo en que estamos") (131).

As Dantisco enumerates excruciating nuances of register, it becomes clear that propriety has become a complicated affair. Not only must each person adjust to regional variations of custom and always obey the usage of the moment, but he or she must apply special forms of address to persons of different rank both in face-to-face encounters and when writing letters. Official government transactions demand a degree of concision that would be considered rude in more informal settings. Older people and youth; servants 
and masters each should cleave to conduct codes specific to their sub-group. If there is any rule of thumb at all, Dantisco recommends imitating the tailor who in cutting fabric for clothing does well to err on the generous side rather than skimp. In other words, it is preferable overdo civility rather than risk being perceived as impolite. Dantisco justifies such vain shows of deference as "burlas o mentiras lícitas"; a sort of social insurance policy necessitated by the pressure to conserve positive face at all times (138).

Although dissimulation constitutes a fundamental doxa of the Galateo español, lexically speaking, few variants of the word 'disumlar' itself appear. ${ }^{37}$ In Chapter 11, "De los encarecimientos", the word shows up as a dangerous enemy tactic. If the victim of an innocent joke should take offense, he or she might dissimulate by smiling but nurse the perceived grievance in secret:

Pues ¿qué sería si son cabeçudos y no se les passe el enojo, aunque duerman sobre ello y dissimulan, con la intención y ánimo dañado y el apariencia alegre? (145).

To avoid becoming vulnerable to dissimulating rivals, the narrator recommends minimizing teasing, jokes and name-calling.

One of Dantisco's most notable departures from della Casa's Galateo is to intercalate an entire novella, "La novela del gran soldán" into his treatise to exemplifiy the art of extended narration. The novella recounts the adventures of a neopolitan prince whose life is to be sacrificed in order to cure the Sultan of Persia of his blindness. Ironically, the doctor who prescribes this bizarre remedy-the Sultan is instructed to eat the prince's heart-- is the Sultan's Christian doctor, who is merely trying to save his own life.

Critics have failed to discern any thematic consonance between the novella and Dantisco's courtesy treatise as a whole. As Morreale dryly puts it, "Lugar aparte en la narrativa del Galateo español, en cuanto al tema si no al estilo, pertenece a la Novela del Gran Soldán"'(57). Certainly none of the three folk-motifs that Morreale identifies-'sovereign's illness cured by captive's blood,' 'youth saved from evil powers with the help of a young maiden with whom he flees,' and 'marriage union thwarted by spell'-bear any

\footnotetext{
37 The first usage, although registered by Autoridades, does not bear on the present discussion: "algunas impertinencias que vemos [en las iglesias] que por su buena intención se dissimulan" [some impertinances that we see that can be excused because they are well-intentioned] (Chapter 4, p. 122). Here dissimular means to excuse or pardon.
} 
obvious relation to the theme of sociability that the Galateo español espouses. But the optic of dissimulation points to another lesson of the novella as a whole: courtesy is a serious matter that could spell the difference between life and death. By providing motivation for acting with discretion, and by investing courtesy with a drama it lacked in daily practice, "La novela del Gran Soldán” fulfills the Galateo españols didactic purpose, that of teaching the rewards of sociability.

True to its generic roots, this miniature byzantine romance brims with secrets, deceits and disguise. But the novel also hews to Aquinas's principle of 'lies committed in the service of a greater good,' a caveat that permits Christian protagonists to lie and dissimulate in order to save their own lives, but denies this state of exception to the (Islamic) enemy.

This double standard is particularly evident early in the novel, as the Sultan's daughter, Axa, hypocritically pampers the captive to keep him happy (until his heart is to be extracted). The Prince of Naples pretends to respond warmly to her advances, in order to win her allegiance and support.

Y como él de suyo fuesse tan agradable y perfecto galán, supo tan bien agradecer y servir con tanta destreza y gallardía a su nueva señora Axa, que ... (158).

The prince's counter-feint succeeds: in a plot-twist propelled by the transformation of dissimulation into authenticity, he wins Axa's true affections:

. . la voluntad fingida y de industria disimulada que ella mostrava se convirtió en un amor entrañable y verdadero (158).

The phrase 'voluntad fingida, y de industria disimulada' marks Axa as a wily schemer. But the prince's equally contrived gallantry passes without reproof, and indeed leads to numerous positive outcomes: the pair's escape, Axa's conversion to Christianity, the cowardly Christian doctor's contrition for placing the prince's life in mortal danger and the prince's eventual marriage to Axa.

Two further explicit uses of the word dissimulation appear in the narrative, and, provided that the Christians are the ones doing the concealing, the narrative justifies the deception. In the first case, the prince returns in disguise to Naples to wed his beloved, and now Christianized Axa. Disguise itself constitutes the dissimulation as it involves the 
omission of information concerning the prince's identity: "El príncipe [llegó] muy dissimulado por no quererse dar a conocer por entonces (160). However, after the prince confesses his identity to one of his captains, he warns him not to show him any special deference that might give him away: "Mas el príncipe le hizo del ojo, y le mandó que dissimulase y le tratasse como a cavallero particular, que no se quería por entonces dar a conocer" (160). The second usage, like the first, involves concealment, but the captain's dissimulation is more active and creative for he is bid to play a part that hides truth.

Once the prince and Axa are betrothed by a bishop, the prince and the doctor return to the Neopolitan court, this time disguised as pilgrims. Disguise allows the men to mingle with other courtiers while gradually 'leaking' hints as to the prince's real identity to soften the shock of their final disclosure:

... entró en la antecámara, y allí después de aver hecho con los cavalleros mil burlas y donaires, con el gozo que tenía se descubrió para que poco a poco dixessen al Rey su padre su venida de suerte que la mucha alegría no le causasse alteración (161).

The pilgrim garb and the altruistic aim of cushioning his parents' shock combine to produce a pious moralistic imperative for deception that contrasts sharply with the text's condemnation of the same techniques when used by the prince's Persian captors.

As the narrative winds to a close, the newly Christianized Axa continues to hide her identity, a ploy the text greets with enthusiasm, and which leads to the novella's happy ending,

"La novela del gran soldán" glamorizes the tedium of civility, making it a matter of urgency and drama rather than merely a wearisome duty or "vana significación de honra y reverencia" (131). Its message reinforces the overall thematic structure of the Galateo español, that of teaching the rewards of amiability. But in order to foreground the struggle between the Persian infidels' barbarism and Christian civility, the narrator is obliged to apply a double standard that disparages pre-baptismal Axa's 'pretense of hospitality,' while painting a more favorable picture of the Christian prince's calculated attentiveness. This double standard suggests that dissimulation could be justified for the sake of achieivng a higher good, either ceremonial (to preserve positive face at court) or transcendent (to save the life of a Christian prince or the soul of an infidel). 
After Dantisco's epistolary narrator concludes the "Novela del gran soldán," attention returns to considerations of style, propriety and purity of language in face-toface interactions at court. Regarding the novella's dependence on strategies of concealment to achieve closure, the only evaluative clue the text provides is to comment by way of introduction that the interpolated novella imitates the "antiguos fabuladores" from whose narratives readers extracted "buenos ejemplos y moralidades" (155). In this manner, the Galateo español nods vaguely at the novella's operations of concealment without explicitly analyzing their implications for courtly conduct. Yet, enfolded within a text that recoils from hypocrisy, obscurantism and hollow show, the "Novela del gran soldán" slips a powerful subliminal endorsement of dissimulation into play, providing a vivid and dramatic template for justifying secrecy as a means to greater ends.

To conclude, in the gap separating the Galateo españols appeal for transparency in courtly speech and action, and its concessions to dissimulation, a bent oar is revealed. Both Dantisco's defense of dissimulating 'por obligación' and the plot-structure of the extended narrative, "La novela del gran soldán" invoke the principle of "officious" or "helpful" lies to justify dissembling at court. Despite its professed disdain for strategies of concealment, the Galateo español rows toward, not away from the culture of secrecy that Saavedra Fajardo and his contemporaries would shortly endorse to steer the ship of state.

Fig. 1: "Con halago i con rigor"

Fig. 2: "Siempre el mismo"

Fig. 3: "Fallimur opinione" 
Fig. 1: "Con halago i con rigor"

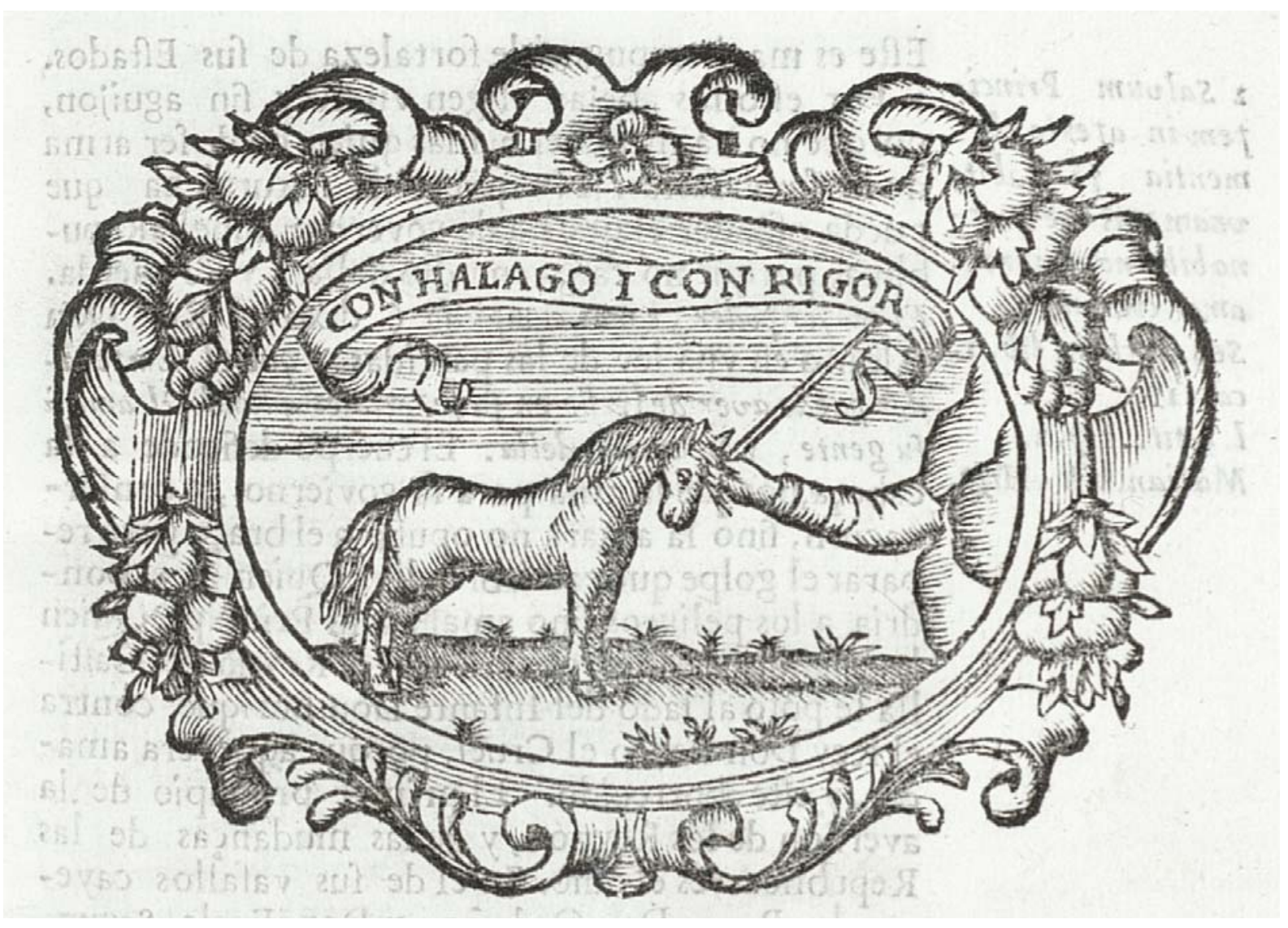


Fig. 2: "Siempre el mismo"

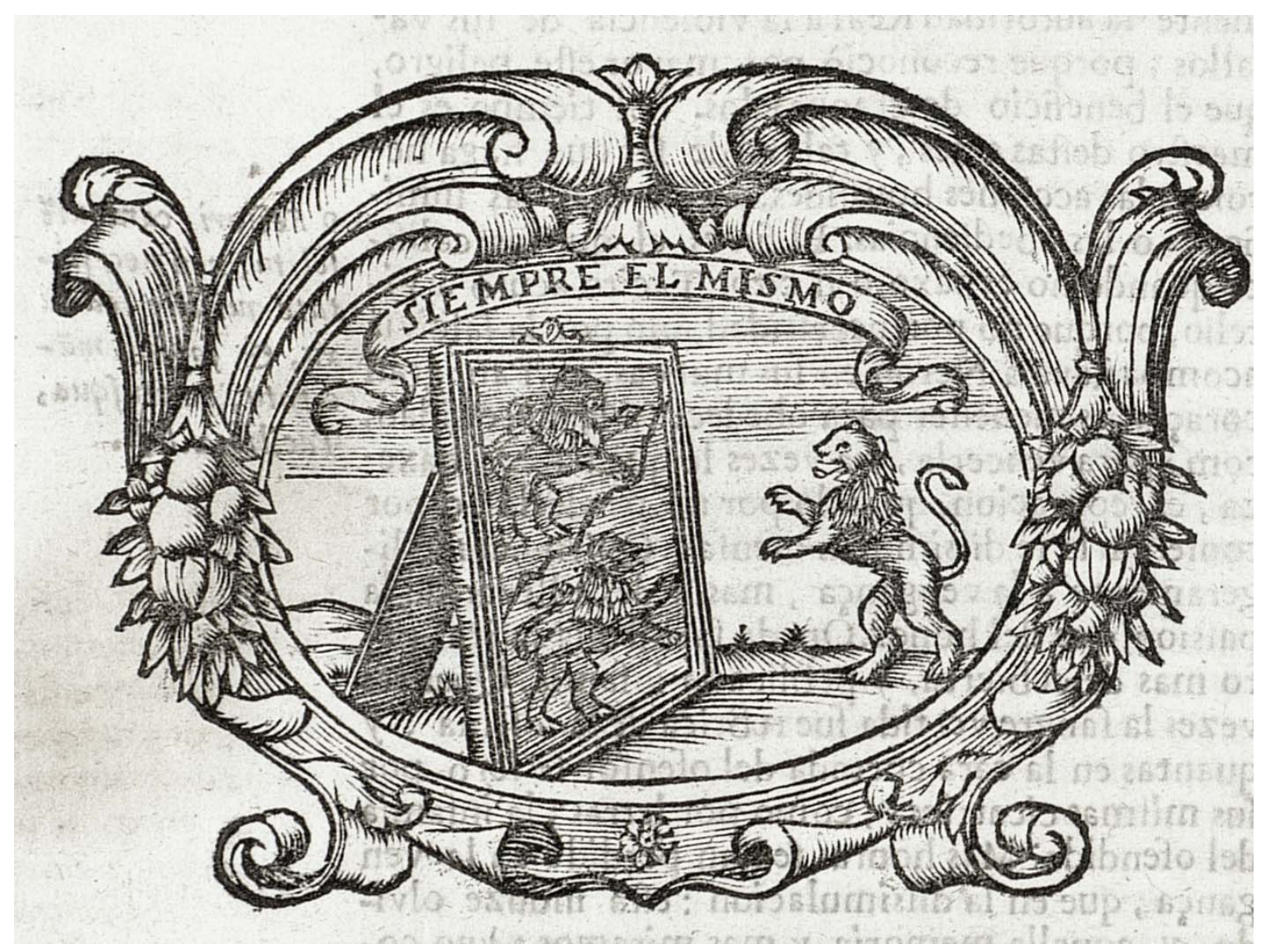


Fig. 3: "Fallimur opinione"

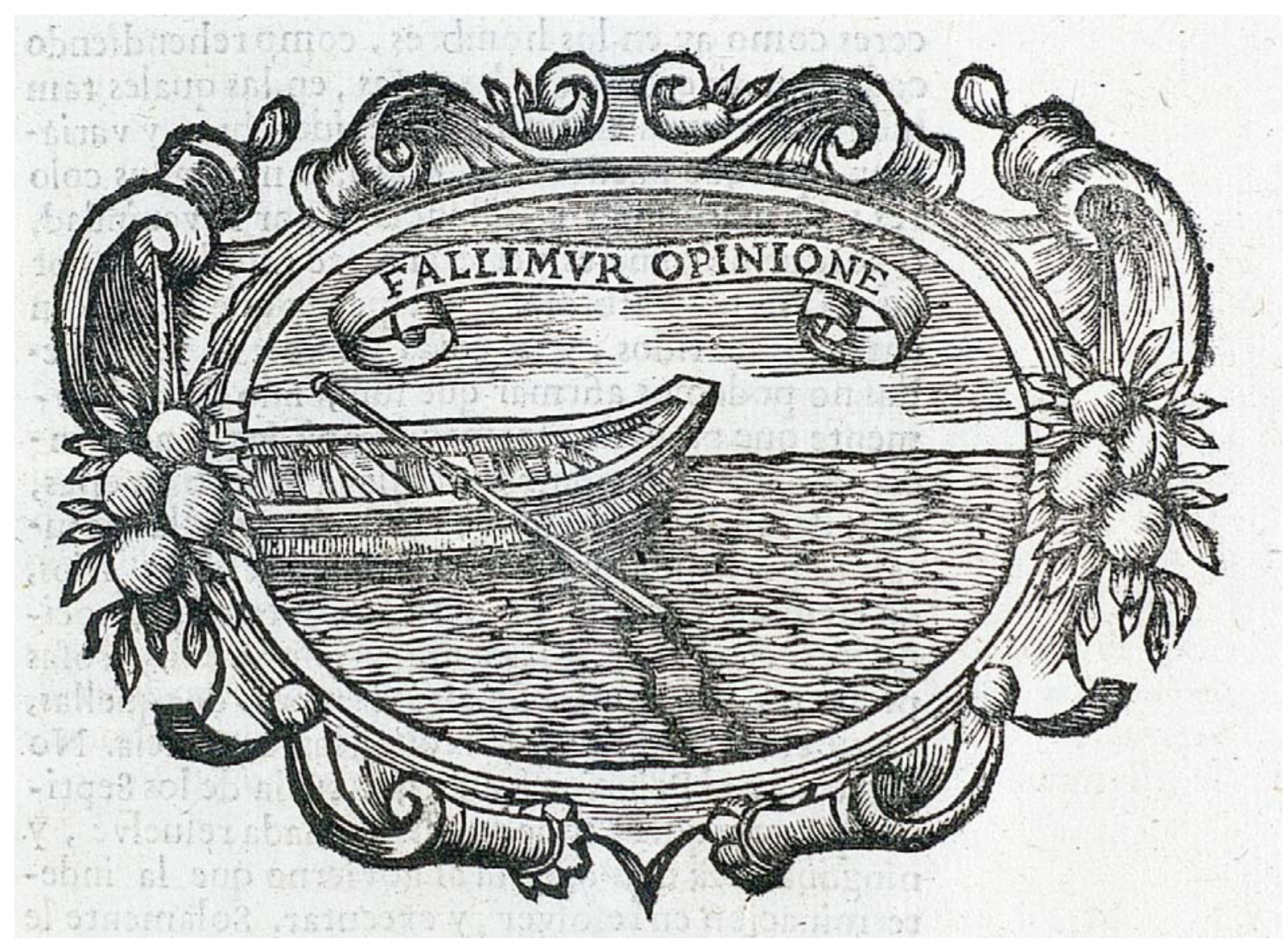

